\title{
The birth and development of the forced expiratory manoeuvre: a tribute to Robert Tiffeneau (1910-1961)
}

\author{
J.C. Yernault
}

\begin{abstract}
The birth and development of the forced expiratory manoeuvre: a tribute to Robert Tiffeneau (1910-1961). J.C. Yernault. OERS Journals Ltd 1997.

ABSTRACT: The forced expiratory manoeuvre was first described by Tiffeneau and Pinelli working in Paris (France), in December 1947, who proposed measurement of the "pulmonary capacity usable on exercise" (capacité pulmonaire utilisable à l'effort) (CPUE), the maximal volume expelled in one second after a deep inspiration. It was intended to replace the measurement of the maximum breathing capacity, a difficult and tiring manoeuvre. A similar approach was later followed in the USA by Gaensler, who proposed the "timed vital capacity" in 1951. The name CPUE was changed to "volume expiratoire maximum seconde" (VEMS) by a group of European experts, who met in Paris on February 13, 1954, whereas the expression "forced expiratory volume" was adopted by the British Thoracic Society in 1957. Despite numerous attempts to examine the forced expiration in a different manner, the VEMS and/or forced expiratory volume in one second (FEV1) remain, after 50 yrs the main variables used daily by the respiratory physician. Although primarily a pharmacologist, Robert Tiffeneau (1910-1961) undoubtedly deserves to figure among the pioneers of respiratory medicine.
\end{abstract}

Eur Respir J 1997; 10: 2704-2710.

Dept of Respiratory Diseases, Hôpital Erasme, Brussels.

Correspondence: J.C. Yernault

Service de Pneumologie

Hôpital Erasme

Route de Lennik 808

B-1070, Bruxelles

Belgium

Received: September 231997

Accepted October 71997
Tiffeneau and Pinelu [1] published the first results of the recording of a forced expiration manoeuvre in Paris Médical on the 27th December 1947. More than 100 yrs had passed between the simple vital capacity (and maximal respiratory pressures) measurement by Hutchinson [2], and their own description of the "capacité pulmonaire utilisable à l'effort" (CPUE), the "pulmonary capacity usable on exercice". In between, spirometry had been considered a very important tool [3], but could not be applied during daily practice!

Before them, few investigators had taken care of the dynamic aspects of ventilation, after early attempts had failed mainly because the available tools were not sufficiently sensitive to follow instantaneous respiratory movements $[3,4]$. For example, the manometric mask proposed by Pецсн [5] in 1921 did not yield adequate values, since the flow he recorded, while a normal subject breathed as rapidly and as vigorously as possible, was $1.75 \mathrm{~L} \cdot \mathrm{s}^{-1}$ ! He further stated that if a subject could only develop a flow below $1.5 \mathrm{~L} \cdot \mathrm{s}^{-1}$, he would be unable to climb two floors without dyspnoea. A more precise evaluation of the dyna-mic behaviour of the respiratory system only became possible after the description of the pneumotachograph by FLEISCH [6]. Soon afterwards ENGLMANN [7] noticed that asthma was characterized by a marked prolongation of the expiratory phase. After epinephrine, however, the expiratory/inspiratory ratio returned to normal [8].

HERMANNSEN [9] was the first to record the maximal ventilatory possibilities during a sustained voluntary effort in 1933. After his description, which remains a landmark in the development of clinical respiratory physiology, several investigators started to relate the sensation of dyspnoea to the maximum breathing capacity (MBC).

Two studies published in 1938 deserve to be quoted. BARACH [10] computed the expiratory and inspiratory flow, and expressed them in cubic centimeters per second. GAUBATZ [11] realized that the level of the $\mathrm{MBC}$ is determined by the size of the vital capacity (VC), and propo-sed to use the ratio $\mathrm{MBC}\left(\mathrm{L} \cdot \mathrm{min}^{-1}\right) / \mathrm{VC}(\mathrm{L})$, which was subsequently called the capacity ratio by MATHESON et al. [12]. These authors made the important observations that the capacity ratio (its mean value found in healthy subjects was 32.8) was independent of the respiratory pressures, at least in normal subjects, but that it decreased during breathing through artificial resistances tubes.

COURNAND (the future Nobel Prize winner) and co-workers [13] observed a striking decrease in the rate of expiration in emphysema. Similarly, GoGgio [14] advocated the use of kymographic tracings of VC, since emphysematous patients may require an abnormally long time to expel a normal amount of air. Gross [15], working in Santiago, Chile, used a chronometer to measure the time necessary for a full maximal expiration. He calculated the expiratory velocities, and expressed them in terms of time (2.9$4.2 \mathrm{~s}$ in normals, mean $3.4 \mathrm{~s}$ ) and in terms of volume per unit time (from 1,110-1,660 $\mathrm{mL} \cdot \mathrm{s}^{-1}$, mean $1,340 \mathrm{~mL} \cdot \mathrm{s}^{-1}$ ). The expiratory velocity remained normal in patients with congestive heart failure (mean $3.4 \mathrm{~s}$ ), whereas the expiratory time was prolonged (mean $4.1 \mathrm{~s}$ ) in cases of respiratory disease. His most striking observation was the decrease in respiratory pressures he observed in heart failure $($ mean $8.9 \mathrm{kPa}(61 \mathrm{mmHg}))$, whereas they remained 
normal (mean $14.9 \mathrm{kPa}(112 \mathrm{mmHg}))$ in respiratory diseases.

While researchers from the other side of the Atlantic became interested in the volume-time relationships, French scientists were trying to find a substitute for the maximum breathing capacity, which they disliked. The reasons that they did not appreciate this manoeuvre were summarized by CARA and SADOUL [16]: the directly measured maximal ventilation is tiring and cannot be repeated more than three to five times during the same session, it is difficult to measure correctly and needs a certain degree of training. They could have added that in asthmatics it can induce an attack of asthma, as already shown by HeRXHEIMER in 1946 [17].

Although Strohl, professor of physics at the Paris Faculty of Medicine, may have been interested in forced respiratory manoeuvres [16], the first publication on the topic dates back to Tiffeneau and Pinell [1]. They had noticed that, during exercise, both the circulating air (now called the tidal volume $(V \mathrm{~T})$ ) and the respiratory frequency $(f R)$ tend to increase, the latter being around 30 breaths $\cdot \min ^{-1}$. They therefore proposed to measure the maximal volume that can be expired in a space of time corresponding to the usual duration of an expiratory phase during exercise. The CPUE was born and was proposed to be equal to the largest volume that can be expired during one second. For this purpose the recording spirometer (a Benedict type in this case) had to be connected to a fast rolling cylinder with a speed of $>2$ to 3 $\mathrm{cm} \cdot \mathrm{s}^{-1}$. Tiffeneau and Pinelui [1] proposed to repeat the CPUE measurements immediately after aerosol admin-istration of either a bronchodilator (a $0.5-1 \%$ aleudrine solution) or a bronchoconstrictor (a 1\% acetylcholine solution). At that time, bronchomotor tests were already commonly used, but only the VC could be measured. This was still the case for CURRY [18] in 1948, who used histamine in asthmatics, and noted that some respiratory distress could occur without change in $\mathrm{VC}$, but with a flattened expiratory phase. Apparently ignoring the work of GRoss [15], Hamburger et al. [19] proposed to evaluate in asthmatics "the air circulation through the bronchi during expiration" by relating the time of a full rapid expiration to the volume of air expelled $(\mathrm{Q})$, calculating the $\mathrm{Q} / \mathrm{T}$ ratio they called the mean expiratory flow ("débit expiratoire moyen").

Thanks to their wide use of bronchomotor tests, TiffeNEAU and PINELLI [20] soon realized that variations in bronchial calibre exert a major effect on CPUE; an index was now available that could characterize the respiratory diseases affecting the airways. It is remarkable that, at the same time, BALDWIN et al. [21] without referring to Tiffeneau's work, proposed their classification, still in common use, of ventilatory insufficiency into two categories, one characterized by "narrowing or partial obstruction of the pulmonary airways", and the other by "restriction in pulmonary expansion and contraction".

Tiffeneau and Pineli [20] recognized three phases during a CPUE manoeuvre:

1) The first phase, at the very beginning of expiration (it is erroneously written inspiration instead of expiration in the original text!), characterized by a rapid increase in speed which reaches its maximum in a very short time (a few hundredths of a second).
2) The second phase having seemingly a uniform speed, expressing itself as a straight line on a spirography.

3) The third phase, where the speed decreases progressively and tends to zero.

They finally observed that during the recording of a spirographic graph the end-expiratory level remains stable, but that it increases during induced bronchial constriction, which results both in an increase in functional residual capacity and residual volume.

OLIVIER and Drutel [22], also analysing the forced expiratory curve, considered it to consist of two segments. Since they regarded the first segment as a straight line, they concluded that the initial flow was both constant and maximum. They proposed to call this initial straight segment the "volume maximum utilisable" (VMU) (maximum volume that can be used) or "vitesse maxima expiratoire" (VME) (maximal expiratory speed). They also proposed to calculate a coefficient of ventilation $(\mathrm{kV}=\mathrm{VMU} / \mathrm{CV}$, where $\mathrm{CV}$ is capacité vitale (vital capacity)). However, their proposal was not very successful and Drutel himself soon measured the CPUE, as reported in his thesis [23]. However, he first considered the relationship between the CPUE and CV and calculated the CV/CPUE ratio. Cara and Sadoul challenged his views (Sadoul P, personal communication), so that he accepted returning to the CPUE/ CV ratio he actually described with TIFFENEAU et al. [24].

Tiffeneau's group made several important observations, which are still largely valid today:

1) The CPUE increases with growth in children, but in adults decreases with ageing; it is $15-30 \%$ lower in females than in males.

2) The CPUE/CV ratio ranges $76-92 \%$ in normals.

3) The expiratory phase can be altered by bronchitis, influenza, or even the common cold.

4) The severity of ventilatory disorders can be classified according to the CPUE level (table 1).

To facilitate the CPUE reading on the spirographic graph, TIFENEAU et al. [24] recommended the use of a rectangular ruler (1.5 $\mathrm{cm}$ wide, which corresponded to $1 \mathrm{~s}$ ), graduated in litres.

Despite the brilliant observations described above, the contribution of French workers remained ignored for a time in the USA. When a handful of North American physiologists met in Atlanta City on April 19, 1950, to standardize the definitions and symbols used in respiratory physiology under the chairmanship of PAPPENHEIMER [25], they did not mention the forced expiratory manoeuvre, and nor did Comroe [26], in his review paper. In their book on emphysema, SEgAL and Dulfano [27] noticed that the timed VC did change with treatment, but they ignored Tiffeneau's work. In fact, from their 176 references, there were only two in German, one in Spanish and one in French.

Table 1. - Classification of the degree of impairment according to the pulmonary capacity (CPUE) level (from TIFFENEAU et al. [24])

\begin{tabular}{ll}
\hline CPUE mL & \multicolumn{1}{c}{ Degree of impairment } \\
\hline$<700$ & Very severe (très important) \\
$700-1000$ & Severe (important) \\
$1000-1500$ & Moderate (moyen) \\
$1500-2000$ & Slight (léger) \\
$2000-2500$ & Very slight (très léger) \\
\hline
\end{tabular}


In the USA, it is to Gaensler's credit that he devoted much work to the analysis of forced expiratory and maximal ventilation. Following the capacity ratio described by MATHESON et al. [12], he proposed to calculate the air velocity index (AVI) by dividing the percentage predicted MBC by the percentage predicted $\mathrm{VC}(\mathrm{AVI}=\mathrm{MBC} \% \mathrm{pred} / \mathrm{VC} \%$ pred), and made measurements in 435 patients [28, 29]. In 23 normal subjects, he found an AVI above 1 (1-1.36, mean 1.07), and similar results after a lobectomy. However, in 36 asthmatics the AVI was reduced (from 0.19 to 0.88). He also noted that the slope of the expiratory tracings was so steep during the first seconds that an accurate measurement of the volume of air could not be ob-tained. $\mathrm{He}$ interposed a spigot between the mouth and the spirometer, which was turned after 3 (or 6) s [30]. By modifying the wheel of the spirometer, he was then able to precisely introduce a time element into the ordinary VC test, and so the timed VC was born [31].

Meanwhile in Europe, Tiffeneau's work was creating much interest, both inside and outside France [32-34]. Among others, workers in Lorraine started measuring lung function in working coal miners [36-38]; for compensation purposes, it was important to make sure that the examined subject was co-operating, and SADOUL and GullLET [36] recommended a close examination of the spirographic graphs instead of a simple reading on a spirometer. To perform a correct manoeuvre, CARA [39] specified that a subject must breathe out as quickly, as strongly and as completely as possible; he also insisted on applying correction factors to barometric pressure and temperature. At that time, he called the forced expiratory manoeuvre the "débit moyen de Tiffeneau", (Tiffeneau's mean flow) and expressed it in litres per second. The index was multiplied by 30 to derive an indirect estimation of the maximal ventilation.

HIRDES and van NeEN [33] correctly observed that the first part of expiration was nearly straight until a critical point $\mathrm{C}$ was reached, after which the expiration slowed down. Since the duration of this first part was usually very close to $1 \mathrm{~s}$, they accepted Tiffeneau's proposal and called this volume the "usable part of $\mathrm{VC}$ " and expressed it as a percentage of VC. They insisted that there might be differences between apparatus, an observation taken up by BERNSTEIN [40] who clearly emphasized the possible mechanical limitation of the recording spirometers.

The timed VC became progessively popular, with SEGAL et al. [41] proposing a ruler with parallel lines, $1 \mathrm{~cm}$ apart, to facilitate the reading of the spirographic graphs, and KenNedy and Stock [42], as well as GiRard et al. [43], showing a correlation between the timed VC and the maximal voluntary ventilation. An important ob-servation was that of LESLIE [44] who found that in em-physema the expiratory VC was sometimes lower than the inspiratory VC. The door was now open for one of the still unresolved controversies in spirometry: to which measured VC should the forced expiratory volume in one second (FEV1) be related?

TifFeneau and Drutel $[45,46]$ realized that the difference between inspiratory and expiratory flows, already noticeable in healthy subjects, became even more pronounced in cases of emphysema. They advocated recording a whole maximum respiratory cycle, the maximal inspiration following the expiration. Their proposal was followed by Bernstein and Kazantris [47]. They also tried to evaluate the calibre of the airways, drawing the "bronchometric chart" [48, 49]: their subjects were brea-thing out through variable calibre diaphragms, until an alteration of the tracing occurred, indicating a reduction in expiratory flow. For any given moment of the expiration, when this phenomenon was detected, they hypothesized that the calibre of the intrathoracic airways was equal to the calibre of the diaphragm. Their method did not stimulate much enthusiasm!

Drutel and Dechoux [50] were the first to report a progressive reduction in the CPUE/CV ratio in adults with ageing; quoting the values obtained by BouRA [51] in his thesis, they found that the ratio decreased from a mean value of $84.5 \%$ in the $20-30$ yrs age group, to $74 \%$ in older subjects (50-65 yrs). After the age of $65 \mathrm{yrs}$, the mean value given by GIRARD et al. [43] was $68.5 \%$. BROCARD and Drutel [52] proposed a minimum normal value of $75 \%$ in adolescents and $70 \%$ in adults. GRaIMPREY [53] emphasized that there is a wide range of normal values for the CPUE, and that a drop of at least $20 \%$ of the mean predicted should be present before deciding that a value is abnormal. It is amazing that his proposal is still frequently followed today, even though it has been repeatedly shown that such an attitude is not supported by hard data [54].

While the "timing of the VC" was progressively overcoming the $\mathrm{MBC}$, much controversy remained about the most convenient time measurement; advocates of $0.75 \mathrm{~s}$ [55] or $2 \mathrm{~s}$ [56, 57] could still be found. SNIDER et al. [58] suggested that the $1 \mathrm{~s}$ VC was less sensitive than the MBC to demonstrate bronchodilator changes. FOWLER et al. $[59,60]$ using pneumotachograms, provided convincing evidence that there was no initial period of sustained constant flow rate, except occasionally in normal persons during somewhat submaximal effort. The acceleration during the first several tenths of a second was, in fact, so large, that an accurate recording of this portion of the trace with a spirometer was considered uncertain. Therefore, they advocated measurement of the average flow over the middle of a rapid maximal expiration: the maximal mid-expiratory flow rate was born [61]. These authors were among the first US scientists to acknowledge the contribution of Tiffeneau and his co-workers. CANDER and Comroe [62] also proposed to ignore the first $200 \mathrm{~mL}$ of expiration and measured the maximum expiratory flow rate between 200 and 1,200 mL of expiration.

Two more series of observations merit special emphasis. Firstly, Schiler and Lowell [63] found in asthma and emphysema that a slow VC is larger than a fast one. Secondly, FRANKLIN et al. [64] observed this apparent paradox: in patients with obstructive disease a maximal effort sometimes yields a slightly slower expiratory rate than a submaximal effort. In Europe, SADoul [65] repeatedly emphasized that forced expiratory manoeuvres should be performed "en souplesse" (flexible). FrankLin et al. [64] also pointed out that, in asthma, physical findings are often misleading and that many patients are poor judges of their condition, and they recommended the spirogram as a useful objective method. As SADOUL and GullLeT [36] before them, they confirmed the superiority of tracings over timers, so that malingering could be easily detected. 
On February 13, 1954, a group of French investigators (table 2), inspired by Denolin*, met in the Hôpital Saint-Antoine in Paris, with a view to establish a common nomenclature. This group, chaired by Sadoul (personal communication) went to a lot of troubles to come to an agreement, but ultimately a new term won: the CPUE was replaced by the VEMS, the "volume expiratoire maximum (ou maximal) seconde", and the VEMS/CV $\times 100$ ratio was recommended. These recommendations, which were accepted on the 15 September 1955 by a further group of experts (table 3 ), were published by BRILL and CARA [66]. The term VEMS became progressively accepted, except by some physiologists, like Dejours [67], who continued to call the volume expired over the first second of expiration the maximal expiratory flow (DEM in French) and to express it in litres per second. In their classical monograph, also published in 1955, COMroE $e t$ al. [68], propsosed to express the "1 s VC" as a percentage of the total volume or the predicted VC; their proposal was, however, not successful.

Despite all these efforts, famous investigators such as Cournand et al. [69], Richards [70, 71], Deale et al. [72], HerschFus and co-workers [73, 74], WOODRUFF et al. [75], FRANK et al. [76], and BATES and co-workers [77, 78] did not yet mention the forced expiration, whereas some tim-ing of the VC was recommended by the American Medical Association [79] and the $3 \mathrm{~s} \mathrm{VC}$ was still receiving some interest [80]. PemberTon and Flanagan [81] emphasized how difficult it may be to separate healthy from diseased subjects. They stated that a $1 \mathrm{~s}$ timed $\mathrm{VC} / \mathrm{VC}$ ratio below $65 \%$ was not necessarily a proof of respiratory disease if not corroborated by other evidence, and that higher values were sometimes found in people "diagnosed on other grounds as having obstructive pulmonary disease".

The year 1957 was another important step in the history of lung function testing. Firstly, ten years after his first work on the subject, TIFFENEAU [82] published his monograph "Examen pulmonaire de l'asthmatique", which summarizes all his work not only on the "VEMS", but also on bronchial provocation. Those interested in the subject can still find important information there; Tiffeneau pointed out that the VEMS absolute level gives information about the degree of ventilatory defect, whereas the "VEMS/CV" ratio gives information about its origin. Secondly, the British Thoracic Society adopted recommendations on terminology for measurements of ventilatory capacity, prepared mainly by 30 British workers, called together by Hugh Jones in December 1956 [83]. They objected to the term "timed VC", because it did not indicate the nature of expiration, and replaced it with the expression "forced expiratory volume over a stated interval of time", and hence the FEV1 and the FEV0.25-0.75. They accepted the FEV1 rather than the FEV 0.75 because it seemed more appropriate for clinical purposes. To calculate a ratio, both the forced VC and the vital capacity (always measured during expiration as done by Hutchinson) were judged acceptable.

*: Prof. Henri Denolin was, with Prof. Paul Sadoul, among the founders and most active members of the former Societas Europea Physiologiae Clinicae Respiratoriae (SEPCR). Throughout his life, he has stimulated exchanges between researchers, mainly in the field of pulmonary circulation and rehabilitation, all around the world. It is interesting to see him already stimulating the Paris meeting. The author of this Historial Note is indebted to this great figure for introducing him to the world of respiratory reaseach.
Table 2. - List of the participants at the 1954 Hôpital Saint-Antoine meeting

\begin{tabular}{|c|c|c|}
\hline Country & City & Name \\
\hline \multirow[t]{4}{*}{ France } & Paris & $\begin{array}{l}\text { B. Ranson-Bitker } \\
\text { M. Traemé } \\
\text { D. Brille } \\
\text { C. Hatzfeld } \\
\text { M. Cara } \\
\text { P. Dejours } \\
\text { P. Drutel } \\
\text { R. Tiffeneau } \\
\text { R. Laurent } \\
\text { A. Pinolli } \\
\text { M. Puisvent } \\
\text { G. Trinquet } \\
\text { D. Jouasset }\end{array}$ \\
\hline & Nancy & $\begin{array}{l}\text { N. Bonfante } \\
\text { P. Pillot } \\
\text { P. Sadoul }\end{array}$ \\
\hline & Merlebach & $\begin{array}{l}\text { Ruyssen } \\
\text { J. Dechoux }\end{array}$ \\
\hline & Lyon & $\begin{array}{l}\text { P. Galy } \\
\text { L. Roche }\end{array}$ \\
\hline Switzerland & Lausanne & $\begin{array}{l}\text { B. Baudras } \\
\text { P.M. Galetti }\end{array}$ \\
\hline Belgium & Louvain-Hasselt & $\begin{array}{l}\text { H. Denolin } \\
\text { A. De Coster } \\
\text { P. Van Cutsem } \\
\text { P. Schmitz } \\
\text { H. Lavenne }\end{array}$ \\
\hline
\end{tabular}

Table 3. - List of the members of the Working Group "Normalisation of lung function tests", who met in Luxembourg on 15 September 1955

\begin{tabular}{ll}
\hline Origin & Name \\
\hline France & D Brille \\
& M Cara \\
& P Sadoul \\
Germany & W Bolt \\
Holland & AVM Mey \\
Italy & M Parsagiklian \\
Belgium & F Lavenne \\
ECCS & A Claass \\
\hline
\end{tabular}

The fiftieth anniversary of Tiffeneau and Pinelli's original paper is a appropriate occasion to review how the concepts of forced expiration developed to finally arrive at a now universally accepted nomenclature, the VEMS in French and the FEV1 in English. It remains strange to see how poorly the French literature seems to have been known, particularly in North America. For instance, in Knowles' monograph, published in 1959, containing 426 references, not a single French paper is mentioned [84]. The French language may have been (and perhaps still is) a barrier: however, Tiffeneau published only one paper in English [85], as well as one in German [86], and in fact they concerned another aspect of his work: the cough reflex induced by the inhalation of acetylcholine [87].

Tiffeneau was basically a pharmacologist and not a respiratory physiologist, working throughout his life on the bronchomotor effects of acetylcholine or histamine and allergens, as well as adrenaline, in asthmatics. Among other major achievements he recognized that adrenaline, 
but not cortisone, protected the asthmatics against their hypersensitivity to acetylcholine and histamine, whereas cortisone reduced their sensitivity to allergens [82, 88]. His observations still form the basis of modern asthma therapy: add a beta-mimetic inhaler to a corticosteroid!

After 50 years, the VEMS and the FEV1 have become an instrument that is used daily by the respiratory physician, whereas other approaches such as the study of the relation between flow (instead of volume) and time [88] have failed. Similarly, more sophisticated analyses of forced expiration within the time domain [89], with a possible revival of $\mathrm{FEV}_{3} \%$, have not become clinical tools. An extensive amount of work has followed to establish the range of values that can be found in healthy subjects and to try to harmonize the procedures among investigators. In Europe they have largely benefited from the continuous support of the European Coal and Steel Community [91]. Despite all these efforts, some controversies are still present, which will only be solved after a proper evaluation. Among others, at least two problems merit attention:

1) The two terms VEMS and FEV1 are in fact not equivalent: measuring the VEMS sometimes needs submaximal, "en souplesse" (flexible), performances, whereas measuring FEV1 implies that a maximal forced expiratory pressure has been generated, whatever the final volume measured. We don't know yet which method is the most informative.

2) The ratios VEMS/CV or FEV1/forced vital capacity (FVC) are commonly reported, but the method of measuring VC may greatly affect the result. In Europe, a preference is now given to a slow inspiratory VC manoeuvre [54], which is in contradiction with Hutchinson's original description [2] of an expiratory manoeuvre which was also adopted by GANDEVIA and Hugh JoNeS [83].

Acknowledgements: Lively oral and written discussions took place with P. Sadoul and P. Hugh Jones who gathered together their souvenirs, as well as several significant papers; their contribution to this historical note has been invaluable. P. Drutel was kind enough to offer a copy of his thesis. G. Huchon has been instrumental in furnishing photocopies of French papers, published in journals that are no longer easily accessible.

\section{References}

1. Tiffeneau R, Pinelli A. Air circulant et air captif dans l'exploration de la fonction ventilatrice pulmonaire. Paris Méd 1947; 37: 624-628.

2. Hutchinson J. On the capacity of the lungs, and on the respiratory functions, with a view of establishing a precise and easy method of detecting disease by the spirometer. Med Chir Trans (London) 1846; 29: 137-252.

3. Jeannel M. Arsenal du diagnostic médical. Thèse de Paris, 1873.

4. Guttmann P. A handbook of Physical Diagnosis, Comprising the Throat, Thorax and Abdomen. 3rd ed. Translated by Napier A. London, The New Sydenham Society, 1879.

5. Plech JL. La notion de débit respiratoire maximal. Presse Méd 1921; 10: 93-94.

6. Fleisch A. Der Pneumotachograph; ein Apparat zur Geschwindigkeitsregistrierung der Atemluft. Pflüg Arch 1925; 209: 713-722.
7. Englmann P. Das pneumotachographische Bild des Asthma bronchiale. Deutsch Arch Klin Med 1927; 157: 280-298.

8. Thiel K, Quednau W. Pneumotachographische Studien. I. Der Einfluss von Medikamenten auf die Asthmakurve. Deutsch Arch Klin Med 1930; 167: 196-207.

9. Hermannsen J. Untersuchungen über die maximale Ventilationgrösse (Atemgrenzwert). Zeitschrift für die gesamte experimentelle medizin 1933; 90: 130-137.

10. Barach AL. Physiological methods in the diagnosis and treatment of asthma and emphysema. Ann Intern Med 1938; 12: 454-481.

11. Gaubatz E. Über Funktionsprüfungen vor und nach der operativen Kollapstherapie. II. Funktionsprüfungen zur Pneumolyse. Beitr Klin Tuberk 1938; 31: 201.

12. Matheson HW, Spies SN, Gray JS, Barnum DR. Ventilatory function tests. II. Factors affecting the voluntary ventilation capacity. J Clin Invest 1950; 29: 682-687.

13. Cournand A, Richards DW Jr, Darling RC. Graphic tracings of respiration in study of pulmonary disease. Am Rev Tuberc 1939; 40: 487-516.

14. Goggio AF. The abnormal physiology of chronic pulmonary emphysema. N Engl J Med 1944; 231: 672.

15. Gross D. Investigations concerning vital capacity. Am Heart J 1943; 25: 335-343.

16. Cara M, Sadoul P. Essai de sémiologie spirographique appliqué à la pneumologie. Poumon 1953; 9: 295-327.

17. Herxheimer H. Hyperventilation asthma. Lancet 1946; i: 83-87.

18. Curry JJ, Lowell FC. Measurement of vital capacity in asthmatic subjects receiving histamine and acetylbeta-methylcholine. A clinical study. J Allergy 1948; 19: 9.

19. Hamburger J, Halpern B, Degeorges. Recherches sur l'asthme bronchique. I. L'épreuve du débit expiratoire moyen. Ann Méd (Paris) 1948; 49: 173-178.

20. Tiffeneau R, Pinelli A. Régulation bronchique de la ventilation pulmonaire. J Fr Méd Chir Thor 1948; 2: 221244.

21. Baldwin E de F, Cournand A, Richards DW Jr. Pulmonary insufficiency. I. Physiological classification, clinical methods of analysis, standard values in normal subjects. Medicine 1948; 27: 243-278.

22. Olivier HR, Drutel P. Etude spirographique d'une expiration forcée. Ann Biol Clin 1949; 7: 343-348.

23. Drutel P. Etude physioclinique des eaux de la Bourboule par la méthode d'exploration de la ventilation pulmonaire. Thèse de Paris, 1949.

24. Tiffeneau R, Bousser J, Drutel P. Capacité vitale et capacité pulmonaire utilisable à l'effort. Critères statique et dynamique de la ventilation pulmonaire. Paris Méd 1949; 39: 543-547.

25. Pappenheimer JR (Chairman). Standardization of definitions and symbols in respiratory physiology. Fed Proc 1950; 9: 602-605.

26. Comroe JH Jr. Interpretation of commonly used pulmonary function tests. Am J Med 1951; 10: 356-374.

27. Segal MS, Dulfano MJ. Chronic Pulmonary Emphysema. Physiopathology and Treatment. New York, Grune \& Stratton, 1953.

28. Gaensler EA. Air velocity index. A numerical expression of the functionally effective portion of ventilation. $A m$ Rev Tuberc 1950; 62: 17-28.

29. Gaensler EA. Ventilatory tests in bronchial asthma. Evaluation of vital capacity and maximum breathing capacity. J Allergy 1950; 21: 232-241.

30. Gaensler EA. Analysis of the ventilatory defect by timed 
capacity measurements. Am Rev Tuberc 1951; 64: 256278.

31. Gaensler EA. An instrument for dynamic vital capacity measurements. Science 1951; 114: 114.

32. Windemuller PJ. Over grenzenen mogelijkheden van de spirographie. Thesis van Utrecht, 1951.

33. Hirdes JJ, van Neen G. Spirometric lung function investigations. II. The form of the expiration curve under normal and pathological conditions. Acta Tuberc Scand 1952; 26: 264-278.

34. Denolin H, De Coster A. Les méthodes d'investigation de la fonction pulmonaire et leurs applications. Acta Tuberc Belg 1952; 43: 245-292.

35. Bolt W, Braun P, Cara M, Knipping HW, Rink H, Sadoul P. Etude sur la fonction respiratoire. Poumon 1953; 9: 296-429.

36. Sadoul P, Guillet M. Le dépistage des simulateurs par l'exploration fonctionnelle. Rev Méd Nancy 1951; 72: 124-136.

37. Hanaut A, Ruyssen L, Cara M. Evolution de la capacité vitale et de la ventilation maxima sous l'influence de l'âge ou de la silicose. Etude et discussion d'une statistique. Arch Mal Prof 1952; 13: 179-189.

38. Sadoul P. Exploration de la fonction pulmonaire dans les pneumoconioses. XXVIIè Congrès de Médecine du Travail (Strasbourg). Cahors, Coueslant, 1954.

39. Cara M. Memento pratique d'un examen fonctionnel élémentaire. Rev Méd Nancy 1951; 72: 185-192.

40. Bernstein L. A critical discussion of the recorded form of the fast vital capacity record. Thorax 1954; 9: 63.

41. Segal MS, Herschfus JA, Dulfano MJ. A simple method for the determination of vital capacity-time relationships. Dis Chest 1952; 22: 123-129.

42. Kennedy MCS, Stock JPP. The bronchodilator action of khellin. Thorax 1952; 7: 43

43. Girard J, Sadoul P, Le Fillattre, Graimprey J. Les moyens d'étude de la ventilation pulmonaire. Limites de confiance. Toulouse Med 1955; 9: 569-577.

44. Leslie A. Inspiratory-expiratory vital capacity test of pulmonary function. Am J Med 1952; 13: 809-812.

45. Tiffeneau R, Drutel P. Acquisitions nouvelles concernant l'emphysème pulmonaire. Sem Hôp Paris 1950; 26: 3965-3977.

46. Tiffeneau R, Drutel P. L'épreuve du cycle respiratoire maximum pour l'étude spirographique de la ventilation pulmonaire. Presse Méd 1952; 60: 640-643.

47. Bernstein L, Kazantzis G. The relation between the fast vital capacity curves and the maximum breathing capacity. Thorax 1954; 9: 326-339.

48. Tiffeneau R, Drutel P. Méthode bronchométrique pour l'étude du calibre bronchique. Presse Méd 1950; 58: $1186-1189$.

49. Tiffeneau R, Drutel P. Facteurs alvéolaires et bronchiques des insuffisances de la ventilation pulmonaire. Sem Hôp Paris 1952; 28: 1717-1730.

50. Drutel P, Dechoux J. Un test spirographique de la perméabilité bronchique: le rapport de la capacité pulmonaire utilisable à l'effort avec la capacité vitale. J Fr Méd Chir Thor 1952; 6: 517-542.

51. Boura M. La ventilation maxima minute. Etude physioclinique.Thèse de Médecine, Nancy, 1951.

52. Brochard H, Drutel P. Etude de la fonction ventilatoire pulmonaire par la méthode spirographique. Technique simplifiée d'examen. Interprétation des résultats. Ann Méd 1955; 56: 537-581.

53. Graimprey J. Les valeurs cites "normales" en spirographie. Rev Méd Nancy 1954; 79: 32-41.
54. Quanjer Ph, Tammeling GJ, Cotes JE, Pedersen OF, Peslin R, Yernault JC. Lung volumes and forced ventilatory flows. Official statement of the European Respiratory Society. Eur Respir J 1993; 6, Suppl. 16: 5-40.

55. Kennedy MCS. A practical measure of the maximum ventilatory capacity in health and disease. Thorax 1953; 8: 73-83.

56. Needham CD, Rogan MC, Mc Donald I. Normal standards for lung volumes, intrapulmonary gas-mixing, and maximum breathing capacity. Thorax 1954; 9: 313-325.

57. Curtis JK, Rasmussen HK, Mendenhall JT. Detection of early pulmonary emphysema. Am Rev Tuberc 1955; 72 : 569-576

58. Snider GL, Barnett HK, Radner DB, Mosko MM. The evaluation of bronchodilator drugs in the treatment of asthma. J Lab Clin Med 1955; 46: 348-358.

59. Fowler WS, Miller ED. Clinical applications of laboratory evaluation of pulmonary function. $M$ Clin N Amer 1954; 38: 1227-1238.

60. Leuallen EC, Fowler WS. Maximal midexpiratory flow. Am Rev Tuberc 1955; 72: 783-800.

61. Miller RD. Current concepts in the diagnosis and treatment of pulmonary emphysema. Arch Intern Med 1955; 96: 360-368.

62. Cander L, Comroe JH Jr. A method for the objective evaluation of bronchodilator drugs. J Allergy 1955; 26: 210-218.

63. Schiller IW, Lowell FC. Pulmonary function in bronchial asthma. J Allergy 1954; 25: 364-378.

64. Franklin W, Michelson AL, Lowell FC, Schiller IW. Clinical value of a tracing of forced expiration. I. Pulmonary disease. N Engl J Med 1955; 253: 798-808.

65. Sadoul P. Mesure de la capacité vitale et des débits maximaux. In: Denolin H, Sadoul P, Orie NGM, eds. L'Exploration Fonctionnelle Pulmonaire. Paris, Flammarion, 1964: 319-413.

66. Brille D, Cara M. Evolution de la terminologie utilisée en physiopathologie respiratoire. Poumon Coeur 1955; 11: 835-842.

67. Dejours P. Physiologie de la respiration. Paris, Flammarion, 1982.

68. Comroe JH Jr, Forster RE II, Dubois AB, Briscoe WA, Carlsen E. The lung. Clinical physiology and pulmonary function tests. Chicago, Year Book, 1955.

69. West JR, Baldwin E de F, Cournand A, Richards DW Jr. Physiopathologic aspects of chronic pulmonary emphysema. Am J Med 1951; 10: 481-496.

70. Richards DW Jr. The nature of cardiac and of pulmonary dyspnea. Circulation 1953; 7: 15-29.

71. Richards DW. The aging lung. Bull NY Acad Med 1956; 32: 407-417.

72. Deale HD, Fowler WS, Comroe JH Jr. Pulmonary function studies in 20 asthmatic patients in the symptom-free interval. J Allergy 1952; 23: 1-10.

73. Herschfus JA, Bresnick E, Segal MS. Pulmonary function studies in bronchial asthma. I. In the control state. Am J Med 1953; 14: 23-33.

74. Herschfus JA, Bresnick E, Segal MS. Pulmonary function studies in bronchial asthma. II. After treatment. Am J Med 1953; 14: 34-40.

75. Woodruff W, Merkel CG, Wright GW. Decisions in thoracic surgery as influenced by the knowledge of pulmonary physiology. J Thorac Surg 1953; 26: 156-183.

76. Frank NR, Cugell DW, Gaensler EA, Ellis LB. Ventilatory studies in mitral stenosis. A comparison with findings in primary pulmonary disease. Am J Med 1953; 15: 60-76.

77. Bates DV. Impairment of respiratory function in bron- 
chial asthma. Clin Sci 1952; 11: 203-207.

78. Bates DV, Knott JMS, Christie RV. Respiration function in emphysema in relation to prognosis. Quart $\mathrm{J} \mathrm{Med}$ 1956; 25: 137-157.

79. Meneely GR. Pulmonary function testing. A special exhibit from the section on diseases of the chest from the American Medical Association. Dis Chest 1957; 31: 125129.

80. Cosby RC, Stowell EC Jr, Hartwig WR, Mayo M. Pulmonary function in left ventricular failure, including cardiac asthma. Circulation 1957; 15: 492-501.

81. Pemberton J, Flanagan EG. Vital capacity and timed vital capacity in normal men over forty. J Appl Physiol 1956; 9: 291-296.

82. Tiffeneau R. Examen pulmonaire de l'asthmatique. Déductions diagnostiques, pronostiques et thérapeutiques. Paris, Masson, 1957.

83. Gandevia P, Hugh Jones P. Terminology for measurements of ventilatory capacity. A report to the Thoracic Society. Thorax 1957; 12: 290-293.

84. Knowles JH. Respiratory physiology and its clinical application. Cambridge, Harvard University Press, 1959.

85. Tiffeneau R. The acetylcholine cough test. Dis Chest
1957; 31: 404-422.

86. Tiffeneau R. Die tussigene Wirkung von AcetylcholinAerosolen. Kriterien der pathologischen Reizbarkeit der sensiblen Nervenenden in der Lungen. Zeitschrift fur Aerosol-Forschung und Therapie. 1955; 4: 116.

87. Tiffeneau R, Drutel P. Les aerosols d'acetylcholine dans l'exploration fonctionnelle des poumons. Etude de leurs action motrice et sensitive. Applications pratiques. Poumon Coeur 1955; 11: 385-468.

88. Tiffeneau R. Activités anti-asthmatiques différentes, mais complémentaires de l'adrénaline et de la cortisone. Bull Acad Méd 1956; 120: 177-180.

89. Campbell EJM, Martin HB, Riley RL. Mechanisms of airway obstruction. Bull Johns Hopkins Hosp 1957; 101: 329-343.

90. Permutt S, Menkes HA. Spirometry. Analysis of for- ced expiration within the time domain. In: Macklem PT, Permutt S, eds. The Lung in Transition Between Health and Disease. New York, Marcel Dekker, 1979: pp.113-152.

91. Jouasset D. Normalisation des épreuves fonctionnelles respiratoires dans les pays de la Communauté Européenne du Charbon et de l'Acier. Poumon Coeur 1960; 16: $1145-1159$. 